\title{
Correction to: Voter ID Laws and Voter Turnout
}

\section{Lauren R. Heller ${ }^{1}$ • Jocelyne Miller ${ }^{1}$. E. Frank Stephenson ${ }^{1}$}

Published online: 14 June 2019

(C) International Atlantic Economic Society 2019

\section{Correction to: Atl Econ J https://doi.org/10.1007/s11293-019-09623-8}

The name of the third author was incorrect in the initial online publication. The original article has been corrected.

The publisher apologizes for the inconvenience caused.

Publisher's Note Springer Nature remains neutral with regard to jurisdictional claims in published maps and institutional affiliations.

The online version of the original article can be found at https://doi.org/10.1007/s11293-019-09623-8

\author{
E. Frank Stephenson \\ efstephenson@berry.edu \\ Lauren R. Heller \\ lheller@berry.edu
}

1 Department of Economics, Berry College, Campus Box 495024, Mount Berry, GA 30149, USA 